\title{
Optimization of synbiotic yogurts with yacon pulp (Smallanthus sonchifolius) and assessment of the viability of lactic acid bacteria
}

\author{
Vivianne Montarroyos PADILHA ${ }^{1 *}$, Samara Alvachian Cardoso ANDRADE ${ }^{1}$, Marcela Sarmento VALENCIA ${ }^{1}$, \\ Tânia Lúcia Montenegro STAMFORD ${ }^{1}$, Silvana Magalhães SALGADO ${ }^{1}$
}

\begin{abstract}
The aim of this study was check the effects of sugar, yacon pulp and skimmed milk powder in the aroma, flavour, texture, appearance, overall impression and intent to purchase on synbiotic yogurts to optimize the formulation using Response Surface Methodology. The most accepted formulations were subjected to viability tests during 21 days by counting traditional and probiotic bacteria. Were constructed a complete $2^{3}$ factorial design, totalling 17 experiments, and considered independent variables (percentage of ingredients) and dependent variables (sensory attributes). All attributes were graded using an acceptability assessment, for this balanced incomplete block was applied. The number of viable cells was determined using specific culture medium for each species. The percentage of yacon pulp had a pronounced negative influence on flavour, texture, appearance, overall impression and intent to purchase. Model predictions adjusted to the variables aroma, flavour, texture, appearance, overall impression and intent to purchase exhibited good predictive ability and hence could be used as tools for process control. Traditional bacterial strains and probiotic remained viable throughout the storage period. The counts of probiotic bacterial in the formulations were above $6 \log$ CFU/g. The addition of Lactobacillus paracasei ssp. paracasei LBC 81 and yacon pulp to yogurt increased product acceptability.
\end{abstract}

Keywords: response surface methodology; fructo-oligosaccharides; L. paracasei ssp. Paracasei LBC 81; sensory analysis.

Practical Application: The innovations of this study are to develop a product with high fructooligosaccharides content originating from the yacon, largest source of fos of nature, and with great potential for cultivation in the Northeast of Brazil. The important points of this were using amounts of ingredients that would allow the acceptance of the product without cripple the growth of probiotic as well as maintain a high score of $L$. paracasei ssp. paracase $i$ LBC 81 throughout the storage period, which is considered to be a challenge in food industry.

\section{Introduction}

The market of food with functional properties in Brazil invoice on average, US\$ 10 billion a year, and worldwide, the segment is expected to grow by $38 \%$ by 2017 , according to the Brazilian Asociación of Diet Food Industries and Special purposes (Asociação Brasileira das Indústrias de Alimentos Dietéticos e para Fins Especiais, 2016). The dairy industry has been outstanding in this respect with the largest number of functional products by addition of probiotics and prebiotics in foods such as yogurt and fermented milk generally (Wendling \& Weschenfelder, 2013; Santos et al., 2011; Sanchez et al., 2009).

Probiotic and synbiotic dairy products are leaders in the functional foods market and are considered research priorities in many countries. The valorization of functional foods worldwide is fostering innovations in food products and stimulating the consumption of foods with important nutritional and therapeutic value (Kumar et al., 2015; Saccaro et al., 2009).

Among the dairy products, yogurt/fermented milks have been the subject of several studies all over the world and different benefits for human health have been reported after their ingestion
(Wang et al., 2012). The regular consumption of probiotics foods can provide the equilibrium of the intestinal microbiota and health benefits (Saad et al., 2013; Vitali et al., 2012). It has been demonstrated that consumption of probiotic can enhance the immune system (Lollo et al., 2013, 2015).

To improve the functionality of the food matrix and facilitate entry of functional foods market, many dairy products are being developed with non-digestible oligosaccharides such as inulin and fructo-oligosaccharides (FOS) as prebiotic ingredients. As such, yacon (Smallanthus sonchifolius) is considered to be the best natural source of FOS and is added to many products to promote healthy intestinal microbiota as these oligosaccharides are selectively fermented in the colon by bifidobacteria and lactobacilli and can therefore provide numerous local and systemic benefits (Oliveira et al., 2016; Sousa et al, 2015; Delgado et al., 2013; Charalampopoulos \& Rastall, 2012; Roberfroid, 2007). The tuberous root of yacon is perennial, thrives in many Andean countries of South America, is generally eaten raw and its colour varies from light to dark yellow (Shi et al., 2015; Velez et al., 2013; Ojansivu et al., 2011). 
Many studies have been made with prebiotics, Cruz et al. (2013a) using oligofructose as a partial replacement of sucrose, developed a plain yogurt and obtained a low calorie product provide an increase in the nutritional benefits without compromising their technological properties. Batista et al. (2015) developed probiotic yogurts with quality parameters positives (probiotic bacteria count, physical-chemical and metabolic activities) with interesting technological option for small and medium-size dairy enterprises to enter to the market of functional dairy foods. Cruz et al. (2013b) results, suggest that the use of packaging systems with different oxygen permeability rates coupled with the addition of glucose oxidase presented an interesting technological option to minimize the oxidative stress in probiotic yogurts. Balthazar et al. (2016) added inulin to sheep milk yogurt smoothies (SMY) and concluded that there was a decreased in post-acidification which aid in bacteria survival and the viability in the food matrix. Morais et al. (2014) developed a prebiotic chocolate dairy dessert adding different concentrations of prebiotics (inulin and FOS) and observed that sensory properties not affected by adding $7.5 \%$ of prebiotics.

Overall, the addition of both prebiotics and probiotics to yogurts has increased their sensory acceptability over products containing only probiotics and conventional products (Allgeyer et al., 2010), reinforcing the idea that the properties of functional foods containing prebiotics and probiotics should be similar to those of the original product (Cruz et al., 2010). However, the probiotic properties will be preserved only if these products maintain a good sensory acceptability and if microorganisms remain viable during shelf life (Komatsu et al., 2008). Thus, the assessment of bacterial viability in a probiotic product is critical for quality evaluation. In this respect, previous studies reported that some commercial products exhibited unacceptably low levels of viable bacteria (Al-Otaibi, 2009; Moreno et al., 2006; Carr \& Ibrahim, 2006).

The amount of ingredients such as sugar and milk powder can influence the viability of probiotic bacteria and the acceptability of yogurts by directly altering their flavour and texture (Dave \& Shah, 1997). Studies that purport to investigate the viability of probiotic bacteria in fermented skim milk produced with different levels of milk powder and sugar can be useful for small dairy industries that are interested in producing flavoured fermented milks without decreasing the viability of probiotic micro-organisms during its shelf life (Maganha et al., 2014).

Therefore, sensory assessments must be conducted with consumers to define the necessary adjustments in the formulation (Ares et al., 2009; Minim, 2013). In this respect, the response surface methodology (RSM) is an effective statistical technique for the establishment of models and processes in which the response of interest, such as sensory acceptability and intent to purchase a product, is influenced by several other variables simultaneously (such as product ingredients), leading to a more efficient and accurate optimization process by reducing the number of experimental studies and product development time and overall research costs (Myers \& Montgomery, 2002). Importantly, RSM efficiently optimizes ingredients and other variables (Ghasemlou et al., 2013; Shen et al., 2011; Granato et al., 2009; Acosta et al., 2008).
Here we aimed to study the effects of sugar, yacon pulp and skimmed milk powder (independent variables) in the aroma, flavour, texture, appearance, overall impression and intent to purchase (dependent variables) on synbiotic yogurts to optimize the formulation using RSM. The most accepted yogurt formulations were subjected to viability tests by counting both the traditional bacteria and the probiotic bacteria added.

\section{Materials and methods}

\subsection{Preparation of the yacon pulp}

Yacon roots were purchased from Ceasa Supply Center of Pernambuco. The other ingredients were obtained from the local market in Recife, Pernambuco State, Brazil.

Roots were washed and sanitized in 200 ppm chlorine solution for $15 \mathrm{~min}$, peeled, cut into $2-\mathrm{cm}$ cubes and soaked in ascorbic acid solution $(0.5 \mathrm{~g} / 100 \mathrm{~g})$ for $5 \mathrm{~min}$. Subsequently, these cubes were bleached at $100^{\circ} \mathrm{C}$ for $5 \mathrm{~min}$, cooled on ice for $2 \mathrm{~min}$ and ground in a food processor. The pulp was concentrated up to $25^{\circ} \mathrm{Bx}$.

\subsection{Preparation of synbiotic yogurts}

Yogurts were prepared with traditional lactic cultures (Streptococcus salivarius thermophilus and Lactobacillus delbrueckii ssp bulgaricus, Danisco YO-MIX 499) and probiotics (L. paracasei ssp paracasei LBC 81, Danisco), which were individually and aseptically transferred to $1 \mathrm{~L}$ of skim milk and stored at $-18^{\circ} \mathrm{C}$. For the inoculation step, cultures were thawed to $37^{\circ} \mathrm{C}$ and $2 \mathrm{~mL}$ of each culture was added to $1 \mathrm{~L}$ of milk for each formulation.

For each experiment, different concentrations of sugar, skimmed milk powder, yacon pulp and $0.3 \%$ of clear unflavoured powdered gelatin were added to $1 \mathrm{~L}$ of UHT whole milk. The independent variables used were as follows: percentage of yacon pulp, $X_{1}$ (5 to $12 \%$ ); percentage of sugar, $X_{2}$ (4 to $9 \%$ ) and percentage of skimmed milk powder, $\mathrm{X}_{3}$ (1 to $6 \%$ ). These ingredients were homogenized and pasteurized at $95{ }^{\circ} \mathrm{C}$ for $2 \mathrm{~min}$, and the mixtures were cooled to $37^{\circ} \mathrm{C}$ and maintained in an incubator at $37^{\circ} \mathrm{C}$ until the $\mathrm{pH}$ reached 4.4 , after which they were stored at $10^{\circ} \mathrm{C}$.

\subsection{Sensory assessment}

The sensory panel was recruited from 50 potential panellists who were firstly subjected to a preliminary screening by a questionnaire, were then further screened for their ability to discriminate between basic tastes based on threshold testing as outlined by the International Organization for Standardization (2007). All participants were familiar with yogurt taste and had previous experience with sensory evaluation. 35 trained adult from the Center for Health Sciences at the Federal University of Pernambuco (23 women and 12 men, 26 to 38 years old) comprising teachers, students and staff, were selected. Panellists were asked to evaluate the aroma, flavour, texture, appearance, overall impression and intent to purchase. Therefore, we used a structured hedonic scale with nine points to grade each attribute, in which the value of 1 represented 'extreme dislike' and that of 9 represented 'extreme like.' For the intent to purchase attribute, 
a 5 -point scale was used, in which the value of 1 represented 'definitely would not buy' and the value of 5 represented 'definitely would buy' (Pandey \& Mishra, 2015). Approximately $40 \mathrm{~g}$ of yogurt were given to the participants in white plastic cups coded with three digits. Panellists used water to rinse their mouth before tasting different samples. Assessments were performed in individual booths and were recorded on a sensory evaluation sheet (Minim, 2013; Pimentel et al., 2013; Meilgaard et al., 2007).

A balanced incomplete block design type III was applied in this study with the following parameters (Hinkelmann \& Kempthorne, 1994; Cochran \& Cox, 1992; Corrêa et al., 2008).

$$
\begin{aligned}
& \mathrm{t}=\text { number of treatments }=15 \\
& \mathrm{k}=\text { number of units per block }=3 \\
& \mathrm{r}=\text { number of repetitions for each sample }=7 \\
& \mathrm{~b}=\text { number of blocks }=35 \text { (number of assessors) } \\
& \lambda=\text { the number of times that each treatment appeared in the } \\
& \text { same block together with each of the other two treatments }=1
\end{aligned}
$$

This design resulted repeated in 70 different trials $(\mathrm{N}=70)$ or responses needed to obtain accurate estimates. Each panellist received three samples of three different formulations, which were presented on different days.

\subsection{Experimental design and statistical analysis}

\section{Response Surface Methodology (RSM)}

For the formulation of synbiotic yogurts, a $2^{3}$ factorial design was constructed to investigate the effects of three independent variables on product acceptability and intent to purchase: concentration of yacon pulp $\left(\mathrm{X}_{1}\right)$, percentage of sugar $\left(\mathrm{X}_{2}\right)$ and percentage of skimmed milk powder $\left(\mathrm{X}_{3}\right)$. These variables were analysed in two equidistant levels of variation (coded as -1 and +1 ), three centre points $(0)$ and six axial points $( \pm \alpha, 0),(0, \pm \alpha)$, totalling 17 experiments (Table 1) (Rodrigues \& Iemma, 2009; Drake et al., 2010). The dependent variables (responses) were aroma, flavour, texture, appearance, overall impression and intent to purchase, and served as quality parameters for the formulations. The data obtained were fitted to the following polynomial equation (Equation 1):

$Y \phi(V, S)=\beta_{0}+\beta_{1} P+\beta_{2} A+\beta_{3} L+\beta_{12} P A+\beta_{13} P L+\beta_{23} A L+\beta_{11} P+\beta_{22} A+\beta_{33} L$

where $\beta \mathrm{n}$ are the regression coefficients; $\mathrm{y}$ is the response in question (sensory attributes and intent to purchase) and P, A, and $L$ are coded variables (percentages of yacon pulp, sugar and milk powder, respectively).

\subsection{Viability of lactic acid bacteria during storage}

The formulations with the highest scores in sensory acceptability and intent to purchase were subjected to a viability test during the 21 -day storage period at $10^{\circ} \mathrm{C}$. For this purpose, a 1-mL aliquot of each sample was transferred to a tube containing $9 \mathrm{~mL}$ of $0.1 \%$ sterile peptone water. This initial dilution was used to make decimal serial dilutions of the yogurts up to the dilution of $10^{7}$. After incubation for each culture medium was complete, cell count was performed in Petri dishes.

The number of viable cells was determined using the pour plate method with 1-mL aliquots. S. thermophilus was counted on the M17 agar medium with the addition of 5\% lactose solution at $10 \%$, followed by aerobic incubation at $37^{\circ} \mathrm{C}$ for $48 \mathrm{~h}$. For counting L. delbrueckii ssp. bulgaricus, MRS agar was used after adjusting the $\mathrm{pH}$ to 5.4 with glacial acetic acid, followed by anaerobic incubation at $37^{\circ} \mathrm{C}$ for $72 \mathrm{~h}$ in GasPak ${ }^{\mathrm{Tm}}$ jars containing an anaerobic generator (International Dairy Federation, 1988).

Direct count of L. paracasei ssp. paracasei LBC 81 was performed using MRS vancomycin agar (Tharmaraj \& Shah, 2003). Approximately $2 \mathrm{~mL}$ of a vancomycin solution $(0.05 \mathrm{~g} / 100 \mathrm{~mL})$,

\begin{tabular}{|c|c|c|c|c|c|}
\hline \multicolumn{3}{|c|}{ Codified (\%) } & \multicolumn{3}{|c|}{ Decodified (\%) } \\
\hline Assays & $\mathrm{X}_{1}$ & $\mathrm{X}_{2} \mathrm{X}_{3}$ & Yacon pulp & Sugar & Skimmed milk powder \\
\hline 1 & -1 & $-1-1$ & 7 & 5 & 2 \\
\hline 2 & 1 & $-1-1$ & 11 & 5 & 2 \\
\hline 3 & -1 & $1-1$ & 7 & 8 & 2 \\
\hline 4 & 1 & $1-1$ & 11 & 8 & 2 \\
\hline 5 & -1 & -11 & 7 & 5 & 5 \\
\hline 6 & 1 & -11 & 11 & 5 & 5 \\
\hline 7 & -1 & 11 & 7 & 8 & 5 \\
\hline 8 & 1 & 11 & 11 & 8 & 5 \\
\hline 9 & -1.68 & 00 & 5 & 6.5 & 3.5 \\
\hline 10 & 1.68 & 00 & 12 & 6.5 & 3.5 \\
\hline 11 & 0 & -1.680 & 9 & 4 & 3.5 \\
\hline 12 & 0 & 1.680 & 9 & 9 & 3.5 \\
\hline 13 & 0 & $0-1.68$ & 9 & 6.5 & 1 \\
\hline 14 & 0 & 01.68 & 9 & 6.5 & 6 \\
\hline 15 & 0 & 00 & 9 & 6.5 & 3.5 \\
\hline 16 & 0 & 00 & 9 & 6.5 & 3.5 \\
\hline 17 & 0 & 00 & 9 & 6.5 & 3.5 \\
\hline
\end{tabular}
previously sterilized by filtration through $0.45-\mu \mathrm{m}$ membranes (Millipore), was added to $1 \mathrm{~L}$ of MRS agar to obtain a final concentration of $1 \mathrm{mg} / \mathrm{L}$. Plates were incubated anaerobically at $37^{\circ} \mathrm{C}$ for $72 \mathrm{~h}$.

Table 1. Experimental design for the preparation of symbiotic yogurts. 


\subsection{Ethical considerations}

This research was approved by the research ethics committee of the Federal University of Pernambuco according to the standards and regulatory guidelines for research involving humans through Resolution CNS 196/96, CAAE - 0345.0.172.000-11. Participation in the study was voluntary and participants were informed about the research and methodological details by reading and signing the Term of Free and Informed Consent established by the National Health Council.

\section{Results}

\subsection{Sensory assessment}

Table 2 shows results of the $2^{3}$ factorial planning for the dependent variables, sensory analysis and intent to purchase. Table 3 indicate that the yacon pulp had a statistically significant negative influence $(\mathrm{p}<0.05)$ in the linear term in all sensory attributes and intent to purchase, with greater influence on flavour, appearance, overall impression and intent to purchase, i.e. smaller percentages of yacon contributed to the achievement of higher scores (Table 2).

The linear term for the sugar concentration had a positive and larger influence on flavour, texture, overall impression and intent to purchase, i.e. higher percentages of sugar contributed to the achievement of the highest scores for these quality parameters.

With regard to the milk powder, this linear term had a greater influence only on texture and intent to purchase (Table 3). We should also emphasize that the interaction between the yacon pulp and skimmed milk had the greatest influence on these attributes.

Table 2 also shows that the formulations 3,7 and 12 exhibited the highest scores for flavour, overall impression and intent to purchase, and did not show any significant differences between

Table 2. Results of the $2^{3}$ factorial planning for the dependent variables 'sensory analysis' and 'intent to purchase'.

\begin{tabular}{|c|c|c|c|c|c|c|c|c|c|}
\hline Samples & $\begin{array}{c}\text { Yacon pulp } \\
(\%)\end{array}$ & Sugar (\%) & $\begin{array}{c}\text { Skimmed } \\
\text { milk powder } \\
(\%)\end{array}$ & Aroma & Flavour & Consistency & Colour & $\begin{array}{c}\text { Overall } \\
\text { impression }\end{array}$ & $\begin{array}{l}\text { Intent to } \\
\text { purchase }\end{array}$ \\
\hline 1 & 7 & 5 & 2 & $6.84 \mathrm{ab}$ & $6.00 \mathrm{~g}$ & $6.10 \mathrm{ef}$ & $6.58 \mathrm{de}$ & $6.20 \mathrm{e}$ & $3.43 \mathrm{~cd}$ \\
\hline 2 & 11 & 5 & 2 & $6.63 d$ & $5.90 \mathrm{gh}$ & $6.38 \mathrm{~cd}$ & $6.40 \mathrm{~g}$ & $6.27 \mathrm{e}$ & $3.22 \mathrm{~d}$ \\
\hline 3 & 7 & 8 & 2 & $6.83 a$ & $7.00 \mathrm{a}$ & $6.40 \mathrm{~cd}$ & $6.73 b c$ & $7.05 \mathrm{a}$ & $3.91 \mathrm{a}$ \\
\hline 4 & 11 & 8 & 2 & $6.66 \mathrm{~d}$ & $6.69 c$ & $6.47 c$ & $6.48 \mathrm{fg}$ & $6.78 b$ & $3.51 b c$ \\
\hline 5 & 7 & 5 & 5 & $6.80 \mathrm{~b}$ & $6.62 \mathrm{~cd}$ & $6.46 c$ & $6.57 \mathrm{de}$ & $6.55 \mathrm{~d}$ & $3.51 b c$ \\
\hline 6 & 11 & 5 & 5 & $6.64 d$ & $5.86 \mathrm{~h}$ & $5.95 \mathrm{e}$ & $6.20 \mathrm{~h}$ & $6.00 \mathrm{f}$ & $3.05 \mathrm{e}$ \\
\hline 7 & 7 & 8 & 5 & $6.79 b c$ & $6.93 a$ & $7.10 \mathrm{a}$ & $6.98 \mathrm{a}$ & $7.15 \mathrm{a}$ & $3.87 \mathrm{a}$ \\
\hline 8 & 11 & 8 & 5 & $6.63 d$ & $6.00 \mathrm{~g}$ & $6.33 \mathrm{~d}$ & $6.32 \mathrm{~g}$ & $6.24 \mathrm{e}$ & $3.18 \mathrm{~d}$ \\
\hline 9 & 5 & 65 & 3.5 & $6.77 \mathrm{bc}$ & $6.30 \mathrm{f}$ & $6.42 \mathrm{c}$ & $6.82 \mathrm{~b}$ & $6.65 c$ & $3.56 \mathrm{~b}$ \\
\hline 10 & 12 & 6,5 & 3.5 & $6.46 \mathrm{e}$ & $5.50 \mathrm{i}$ & $6.05 f$ & $6.02 \mathrm{i}$ & $5.98 \mathrm{f}$ & $2.78 \mathrm{f}$ \\
\hline 11 & 9 & 4 & 3.5 & $6.69 \mathrm{~cd}$ & $6.37 f$ & $6.15 \mathrm{e}$ & $6.58 \mathrm{de}$ & $6.20 \mathrm{e}$ & $3.36 c$ \\
\hline 12 & 9 & 9 & 3.5 & $6.68 c$ & $7.29^{a}$ & $6.72 b$ & $6.48 \mathrm{fg}$ & $7.13 \mathrm{a}$ & $3.91 \mathrm{a}$ \\
\hline 13 & 9 & 6.5 & 1 & $6.95 \mathrm{a}$ & $6.51 \mathrm{de}$ & $6.43 c$ & $6.68 \mathrm{~cd}$ & $6.69 b c$ & $3.61 b$ \\
\hline 14 & 9 & 6.5 & 6 & $6.88 \mathrm{ab}$ & $6.42 \mathrm{ef}$ & $6.61 b$ & $6.77 b$ & $6.53 d$ & $3.42 \mathrm{c}$ \\
\hline 15 & 9 & 6.5 & 3.5 & $6.61 d$ & $6.49 \mathrm{e}$ & $6.38 \mathrm{~cd}$ & $6.53 \mathrm{ef}$ & $6.52 \mathrm{~d}$ & $3.37 c$ \\
\hline 16 & 9 & 6.5 & 3.5 & $6.65 \mathrm{~d}$ & $6.50 \mathrm{e}$ & $6.40 \mathrm{~cd}$ & $6.58 \mathrm{de}$ & $6.50 \mathrm{~d}$ & $3.35 c$ \\
\hline 17 & 9 & 6.5 & 3.5 & $6.63 \mathrm{~d}$ & $6.47 \mathrm{e}$ & $6.37 \mathrm{~cd}$ & $6.60 \mathrm{de}$ & $6.55 \mathrm{~d}$ & $3.34 \mathrm{c}$ \\
\hline
\end{tabular}

Mean values followed by the same letter indicate non-significant differences by the Duncan test at a $5 \%$ significance level.

Table 3. Estimate of the effects on the sensory attributes (aroma, flavour, texture, appearance and overall impression) and intent to purchase.

\begin{tabular}{|c|c|c|c|c|c|c|}
\hline Factor & Aroma & Flavour & Consistency & Colour & $\begin{array}{c}\text { Overall } \\
\text { impression }\end{array}$ & $\begin{array}{l}\text { Intent to } \\
\text { purchase }\end{array}$ \\
\hline Average & 6631 & 6.475 & 6.38 & 6.557 & 6.518 & 3.345 \\
\hline Yacon pulp (L) & -0.182 & -0.584 & -0.246 & -0.429 & -0.435 & -0.47 \\
\hline Sugar $(\mathrm{L})$ & NS & 0.557 & 0.348 & 0.087 & 0.553 & 0.321 \\
\hline Sugar (Q) & NS & 0.246 & 0.041 & NS & 0.108 & 0.217 \\
\hline $\mathrm{PxS}$ & NS & -0.095 & -0.117 & NS & -0.175 & -0.105 \\
\hline PxM & NS & -0.32 & -0.407 & -0.15 & -0.315 & -0.135 \\
\hline SxM & NS & -0.335 & 0.157 & NS & -0.13 & -0.07 \\
\hline$R^{2}$ & 0.991 & 0.994 & 0.998 & 0.897 & 0.998 & 0.994 \\
\hline
\end{tabular}

L: linear; Q: quadratic; P: yacon pulp; S: sugar; M: skimmed milk powder; R²: coefficient of determination of the equation. 
them $(\mathrm{p}>0.05)$, but differed significantly $(\mathrm{p}<0.05)$ from the other formulations.

Table 2 indicates that the highest percentages of sugar and the lowest percentages of yacon pulp contributed to the higher scores exhibited by formulations 3, 7 and 12, differently from formulations 1 and 5, which had lower percentages of sugar and yacon pulp.

Formulations 3, 7 and 12 exhibited scores close to 7 for overall impression, meaning that participants liked the formulation moderately and a score close to 4 for intent of purchase, indicating that participants would probably buy the product (Table 2).

Models were calculated for each of the dependent variables and only statistically different parameters were included $(\mathrm{p}<0.05)$ (Table 4). The models that were adjusted for aroma, flavour, texture, overall impression and intent to purchase showed coefficients of determination and coefficient of appearance to be greater than 0.99 and equal to 0.89 , respectively.

The proximity of the coefficient of determination of the equation to 1.0 demonstrated the validity of the regression equation and hence the absence of non-significant fit for each model ( $p>0.05)$. Therefore, the coefficients of determination for the predicted model for aroma, flavour, texture, appearance, overall impression and intent to purchase were valid, considering that response variables were hedonic sensory measures, which often exhibit considerable variations.

Figure 1A-H shows the construction of response surfaces according to each model. Figure 1A shows that the surface created by the predictive model for flavour acceptability enabled better determination of formulation optimization using a lower percentage of yacon pulp and a higher percentage of sugar. The highest scores for flavour were obtained with 7 to $9 \%$ of yacon pulp and 8 to $10 \%$ of sugar. With regard to the relationship between yacon pulp and sugar, the same behaviour could be observed in relation to texture, overall impression and intent to purchase, as shown in Figure 1B, F, H, respectively. These results corroborate those found in the estimate of the effects (Table 3).

Figure $1 \mathrm{C}$ shows that the highest scores for texture were obtained with a higher percentage of milk powder and the lowest scores were obtained for appearance in relation to sugar concentration (Figure 1D).

Figure $1 \mathrm{E}$ shows that the smallest percentages of yacon pulp and the largest percentages of milk powder exhibited the greatest influence on product appearance, corroborating the negative effect of the interaction between yacon pulp and milk powder (Table 3).

\subsection{Culture viability during storage}

Table 5 shows the direct counts for the traditional lactic acid bacteria $S$. salivarius ssp. thermophilus and L. delbrueckii ssp. bulgaricus and for the probiotic culture during storage at $10^{\circ} \mathrm{C}$. Formulations 3, 7 and 12 exhibited the highest scores of acceptability and intent to purchase and were designated A, B and $\mathrm{C}$, respectively. In general, formulation $\mathrm{B}$ permitted a lower bacterial growth.

Table 4. Estimated models for the sensory attributes and the intent to purchase.

\begin{tabular}{llcc}
\hline \multicolumn{1}{c}{ Responses } & \multicolumn{1}{c}{ Model } & $R^{2}$ & \multicolumn{1}{c}{ Lack of fit (P) } \\
\hline Aroma & $7.80-0.330 \mathrm{M}+0.044 \mathrm{M}^{2}$ & 0.991 & 0.715 \\
Flavour & $1.066 \mathrm{P}-0.051 \mathrm{P}^{2}+0.055 \mathrm{~S}^{2}+0.974 \mathrm{M}-0.016 \mathrm{PS}-0.053 \mathrm{PM}-0.074 \mathrm{SM}$ & 0.994 & 0.06 \\
Consistency & $3.120+0.547 \mathrm{P}-0.013 \mathrm{P}^{2}+0.009 \mathrm{~S}^{2}+0.264 \mathrm{M}+0.023 \mathrm{M}^{2}-0.019 \mathrm{PS}-0,068 \mathrm{PM}+0,035 \mathrm{SM}$ & 0.998 & 0.459 \\
Colour & $4.912+0.338 \mathrm{P}-0.014 \mathrm{P}^{2}+0.025 \mathrm{M}^{2}-0.025 \mathrm{PM}$ & 0.897 & 0.073 \\
Overall impression & $1.982+0.622 \mathrm{P}-0.020 \mathrm{P}^{2}+0.236 \mathrm{~S}+0.024 \mathrm{~S}^{2}+0.523 \mathrm{M}+0.015 \mathrm{M}^{2}-0.029 \mathrm{PS}-0.052 \mathrm{PM}-0.029 \mathrm{SM}$ & 0.991 & 0.649 \\
Intent to purchase & $2.775+0.381 \mathrm{P}-0.017 \mathrm{P}^{2}-0.309 \mathrm{~S}+0.048 \mathrm{~S}^{2}+0.029 \mathrm{M}^{2}-0.017 \mathrm{PS}-0.022 \mathrm{PM}-0.015 \mathrm{SM}$ & 0.994 & 0.141 \\
\hline
\end{tabular}

P: yacon pulp and S: sugar; M: skimmed milk powder; $\mathrm{R}^{2}$ : coefficient of determination.

Table 5. Viability of bacteria (log CFU/g) used in yogurt fermentation during refrigerated storage at $10^{\circ} \mathrm{C}$ for 21 days.

\begin{tabular}{|c|c|c|c|c|}
\hline Formulations & Days of storage & S. themophilus ${ }^{*}$ & L.bulgaricus $^{*}$ & L. paracasei* \\
\hline \multirow{4}{*}{ Yogurt A } & $\mathrm{d} 1$ & $8.60^{\mathrm{Aa}}(0.11)$ & $8.40^{\mathrm{Ba}}(0.10)$ & $7.08^{\mathrm{Bb}}(0.07)$ \\
\hline & $\mathrm{d} 7$ & $8.66^{\mathrm{Aa}}(0.12)$ & $7.21^{\mathrm{Ab}}(0.14)$ & $7.23^{\mathrm{Aa}}(0.13)$ \\
\hline & $\mathrm{d} 14$ & $7.97^{\mathrm{Ab}}(0.10)$ & $7.18^{\mathrm{Ab}}(0.16)$ & $6.28^{\mathrm{Bc}}(0.06)$ \\
\hline & $\mathrm{d} 21$ & INC & $8.38^{\text {Aa }}(0.11)$ & $7.36^{\mathrm{Aa}}(0.11)$ \\
\hline \multirow{4}{*}{ Yogurt B } & $\mathrm{d} 1$ & $7.00^{\mathrm{Bb}}(0.14)$ & $7.76^{\mathrm{Ca}}(0.19)$ & $6.69^{\mathrm{Cc}}(0.04)$ \\
\hline & $\mathrm{d} 7$ & $8.60^{\text {Aa }}(0.15)$ & $6.78^{\mathrm{Bc}}(0.14)$ & $6.95^{\mathrm{Bb}}(0.08)$ \\
\hline & $\mathrm{d} 14$ & $5,0^{\mathrm{Cc}}(0.11)$ & $7.04^{\mathrm{Bb}}(0.09)$ & $7.18^{\mathrm{Aa}}(0.11)$ \\
\hline & $\mathrm{d} 21$ & INC & $6.84^{\mathrm{Cc}}(0.11)$ & $6.95^{\mathrm{Cb}}(0.07)$ \\
\hline \multirow{4}{*}{ Yogurt C } & $\mathrm{d} 1$ & $8.65^{\text {Аa }}(0.17)$ & $8.58^{\mathrm{Aa}}(0.10)$ & $7.15^{\mathrm{Ab}}(0.08)$ \\
\hline & $\mathrm{d} 7$ & $8.66^{\mathrm{Aa}}(0.18)$ & $7.23^{\mathrm{Ab}}(0.08)$ & $7.21^{\mathrm{Aa}}(0.11)$ \\
\hline & $\mathrm{d} 14$ & $7.55^{\mathrm{Bb}}(0.14)$ & $6.18^{\mathrm{Cc}}(0.07)$ & $6.00^{\mathrm{Cc}}(0.07)$ \\
\hline & $\mathrm{d} 21$ & UNC & $7.11^{\mathrm{Bb}}(0.10)$ & $7.23^{\mathrm{Ba}}(0.12)$ \\
\hline
\end{tabular}

\footnotetext{
${ }^{\text {abc }}$ Means followed by the same lowercase letters vertically along the days of storage in the same yogurt formulation indicate non-significant differences ( $p>0.05$ ) by the Duncan test.

${ }^{\mathrm{ABC}}$ Means followed by capital letters vertically between the yogurt formulations on the same day of storage indicate non-significant differences ( $\mathrm{p}>0.05$ ) by the Duncan test. ${ }^{\star}$ Mean and standard deviation are shown in parentheses. UNC: Uncountable; CFU/g: Colony Forming Units/g.
} 


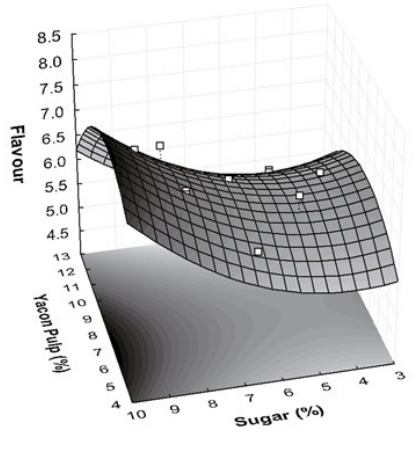

A

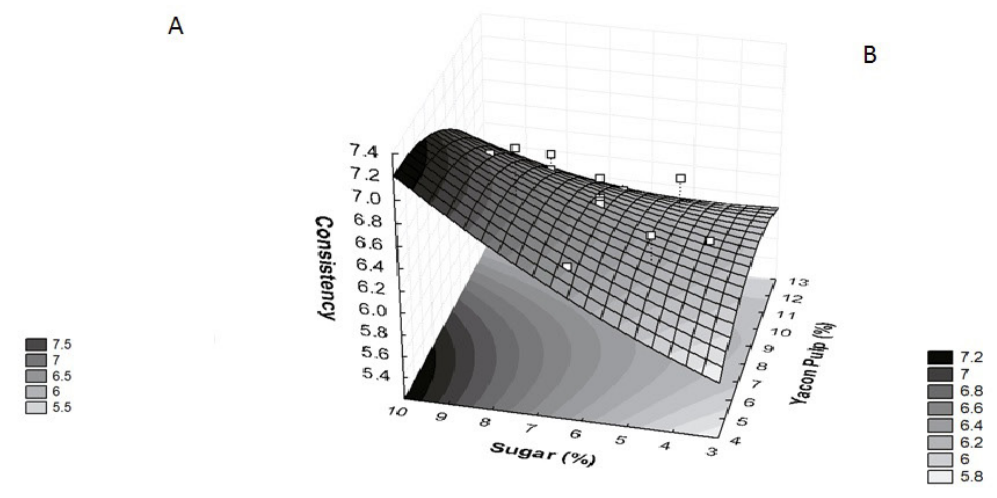

C

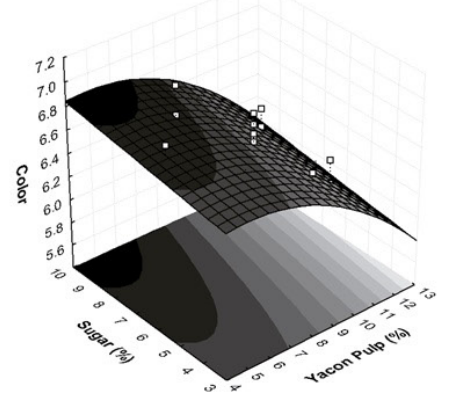

D

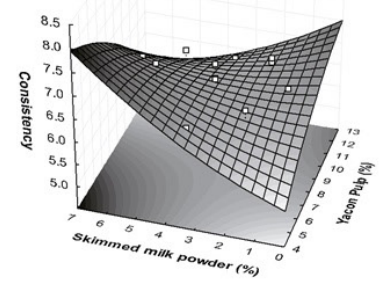

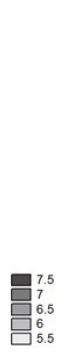

$\mathrm{E}$
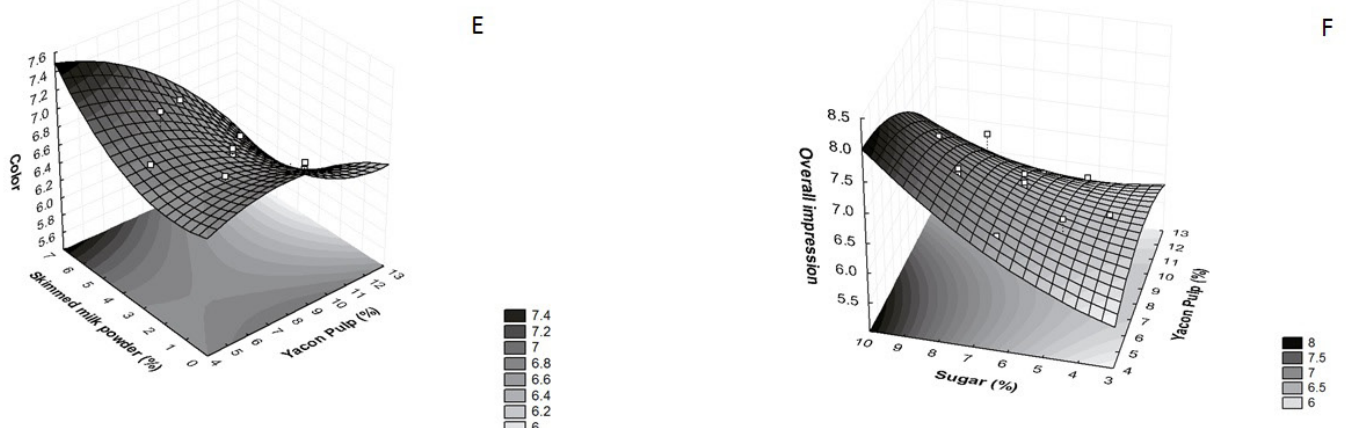

G

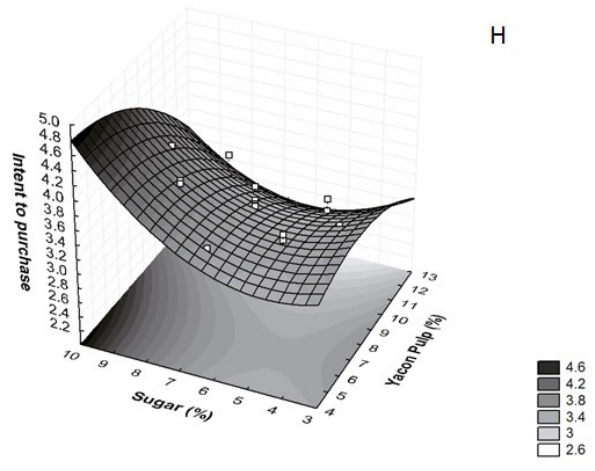

Figure 1. Responses surfaces for sensory ou sensorial attributes. (A) Flavour as a function of yacon pulp (\%) and sugar (\%); (B) Consistency as a function of sugar (\%) and yacon pulp (\%); (C) Consistency as a function of skimmed milk powder (\%) and yacon pulp (\%); (D) Color as a function of sugar (\%) and yacon pulp (\%); (E) Color as a function of skimmed milk powder (\%) and yacon pulp (\%); (F) Overall impression as a function of sugar (\%) and yacon pulp (\%); (G) Overall impression as a function of skimmed milk powder (\%) and yacon pulp (\%); (H) Intent of purchase as a function of sugar (\%) and yacon pulp (\%). (9-points scale: $1=$ extreme dislike; $9=$ extreme like) and intent to purchase (5-points scale: 1 = definitely would not bu; 5 = definitely would buy). 
At the $21^{\text {st }}$ day of storage, S. thermophilus predominated over the other microorganisms. Moreover, probiotic bacteria remained viable throughout the shelf-life period.

\section{Discussion}

\subsection{Sensory assessment}

The highest percentage of sugar in the yogurt formulations positively influenced the flavour, texture, overall impression and intent to purchase. In general, yogurts containing fruit pulp and higher contents of sugar are preferred by the Brazilian consumers. Although sugar was added to products, FOS may have contributed only slightly to the sweetness of the formulations, as it exhibits only 30 to $35 \%$ of the sweetness of sucrose (Coussement, 1999; Franck, 2006). Notably, flavour is one of the most important factors influencing the decision to purchase foods (Drewnowski \& Darmon, 2005; Glanz et al., 1998).

The little influence of the yacon pulp on the aroma may be related to the high moisture content of this root. In Quechua, both yacu and unu indicate water, whereas yakku indicates watery or tasteless, hence the neutral and smooth aroma of yacon (Delgadoet al., 2013; Moscatto et al., 2006).

Sugar most influenced the texture of yogurt. We also observed that the texture increased with a higher percentage of milk powder and a lower percentage of yacon pulp. This result contradicts the literature, which has reported that the presence of FOS is responsible for the increase in food texture (Saad et al., 2013). On the other hand, Karimi et al (2015) mentions that when FOS added to food in low concentrations, the rheological properties and the sensory quality of the product will not be affected strongly due to FOS neutral or slightly sweet taste and its limited effect on viscosity.

Because of the Maillard reaction, skimmed milk powder was the ingredient that most influenced the appearance of the formulations. We also observed that the fructo-oligosaccharides present in yacon are non-reducing sugars and hence are not susceptible to the Maillard reaction (Niness, 1999).

This study corroborates the data found in previous studies with regard to the high coefficients of determination. In an assessment of a low-calorie gelatin made of tropical fruits, by varying the percentage of sweetener, pectin with a low degree of methoxylation, and calcium, the response variables yielded significant adjusted models $(\mathrm{p}=0.014)$ and no significant lack of fit ( $p=0.253$ ) (Acosta et al., 2008). The acceptability of low-fat, prebiotic dairy beverages was evaluated by 50 customers and with a 9-point hedonic scale using short- and long-chain inulins. The model indicated a coefficient of determination of 0.87 for the formulation prepared with short-chain inulin and a coefficient of 0.86 for long-chain inulin, and neither of them showed lack of fit, with values of $p=0.217$ and $p=0.023$, respectively (Villegas et al., 2010).

\subsection{Viability}

Total counts of the lactic bacterial strains S. thermophilus and L. delbrueckii ssp. bulgaricus, which are common in yogurt, were above the required minimum of $10^{7}$ viable microorganisms per gram (Food and Agriculture Organization of the United Nations, 2003). This density meets the standards established by the Brazilian legislation, and according to the Standards of Identity and Quality of Fermented Milk (through Normative Instruction 46 from 10/23/2007), must be at least $10^{7} \mathrm{UFC} / \mathrm{g}$ in the final product throughout the validity period for the fermented milk to be considered a yogurt (Brasil, 2007).

The larger percentages of sugar and milk powder used in formulation B may have led to a decrease in the amount of water and hence decreased the ability of microorganisms to multiply. The solid content and sugar concentration (i.e. osmotic pressure) have been shown to directly influence the population of lactic acid bacteria (Shah \& Ravela, 2000; Vinderola et al., 2000). Therefore, the results of this study corroborate previous reports. Although our formulations had 8 or $9 \%$ of sugar, this percentage did not hinder the growth of lactic acid bacteria to the point of yielding a low bacterial count.

In beverages fermented with $S$. thermophilus, L. delbrueckii ssp. bulgaricus, Bifidobacterium and L. acidophilus, S. thermophilus has been reported to predominate over the other microorganisms, similar to what we observed in the present study (Thamer \& Penna, 2005).

The total counts of $L$. paracasei ssp. paracasei LBC 81 were above the threshold for probiotic microorganisms added to yogurts (Food and Agriculture Organization of the United Nations, 2003). Also, their survival until the $21^{\text {st }}$ day of storage at $10{ }^{\circ} \mathrm{C}$ suggests that our yogurt formulations provided a good food matrix for the growth and viability of this microorganism. The legislation of many countries considers that the bacterial population must be viable during storage, but the minimum levels established for an effective quantification may vary from $10^{6}$ to $10^{8} \mathrm{UFC} / \mathrm{g}$, according to local regulations.

The Brazilian legislation has established that the minimum amount of viable probiotic bacteria in yogurts should be between 6 and $7 \log$ CFU/100g/day (Brasil, 1999, 2003). The three yogurt formulations used in this study were considered 'probiotic' during a shelf life period of 21 days, confirming what has been reported on the positive interaction between L. paracasei ssp. paracasei LBC co-cultured with S. thermophilus and L. delbrueckii spp. bulgaricus. This co-culture application also has contributed to the production of a final product with satisfactory aroma, flavour, texture and acidity characteristics (Kristo et al., 2003; Saarela et al., 2000). It has also been reported that the viability of the probiotic strain L. paracasei ssp. paracasei B1 17 co-cultured with S. thermophilus Y4.10 and L. delbrueckii spp. bulgaricus Y6.15 in fermented milk was greater than 6 log CFU/g during storage at $4{ }^{\circ} \mathrm{C}$ for 21 days (Kristo et al., 2003).

Previous data have indicated that the use of growth factors as prebiotics (such as FOS in yacon pulp) and milk proteins are very important for the maintenance of bacterial viability because these growth factors affect the kinetics of acidification (Nogueira, 2009; Oliveira et al., 2002). Corroborating our results, the addition of milk proteins has stimulated the multiplication of L. rhamnosus and L. paracasei (Saxelin et al., 1999). In a previous study where prebiotics, inulin and polydextrose were added to yogurts made with banana puree and $L$. paracasei, the number 
of probiotic bacteria remained high at $8.86 \mathrm{log} \mathrm{CFU} / \mathrm{g}$ during the 21-day storage period (Srisuvor et al., 2013).5 Conclusions

The percentage of yacon pulp had a pronounced negative influence on flavour, texture, appearance, overall impression and intent to purchase. The percentage of sugar had a greater positive influence on flavour, texture, overall impression and intent to purchase. Model predictions adjusted to the variables aroma, flavour, texture, appearance, overall impression and intent to purchase exhibited good predictive ability and hence could be used as tools for process control. In the yogurt formulations studied, traditional bacterial strains and $L$. paracasei ssp. paracase $i$ LBC 81 remained viable throughout the storage period.

\section{Acknowledgements}

The authors are thankful to the National Council for Scientific and Technological Development (CNPq) for financially supporting this study (Project N. 471970/2011-5).

\section{References}

Acosta, O., Víquez, F., \& Cubero, E. (2008). Optimisation of low calorie mixed fruit jelly by response surface methodology. Food Quality and Preference, 19(1), 79-85. http://dx.doi.org/10.1016/j. foodqual.2007.06.010.

Allgeyer, L. C., Miller, M. J., \& Lee, S. Y. (2010). Drivers of liking for yoghurt drinks with prebiotics and probiotics. Journal of Food Science, 75(4), 212-219. PMid:20546424. http://dx.doi.org/10.1111/j.17503841.2010.01579.x.

Al-Otaibi, M. M. (2009). Evaluation of some probiotic fermented milk products from Al-Ahsa markets, Saudi Arabia. American Journal of Food Technology, 4(1), 1-8. http://dx.doi.org/10.3923/ajft.2009.1.8.

Ares, G., Baixauli, R., Sanz, T., Varela, P., \& Salvador, A. (2009). New functional fibre in milk puddings: effect on sensory properties and consumers' acceptability. LWT -. Food Science and Technology (Campinas.), 42(3), 710-716.

Asociação Brasileira das Indústrias de Alimentos Dietéticos e para Fins Especiais. (2016). São Paulo: Abiad. Retrieved from http// www.abiad.org.br

Balthazar, C. F., Conte, C. A. Jr., Moraes, J., Costa, M. P., Raices, R. S. L., Franco, R. M., Cruz, A. G., \& Silva, A. C. (2016). Physicochemical evaluation of sheep milk yogurts containing different levels of inulin. Journal of Dairy Science, 99(6), 4160-4168. PMid:26995125. http:// dx.doi.org/10.3168/jds.2015-10072.

Batista, A. L. D., Silva, R., Cappato, L. P., Almada, C. N., Garcia, R. K. A., Silva, M. C., Raices, R. S. L., Arellano, D. B., Sant’Ana, A. S., Conte, C. A. Jr., Freitas, M. Q., \& Cruz, A. G. (2015). Quality parameters of probiotic yogurt added to glucose oxidase compared to commercial products through microbiological, physical-chemical and metabolic activity analyses. Food Research International, 77(3), 627-635. http:// dx.doi.org/10.1016/j.foodres.2015.08.017.

Brasil. Agência Nacional de Vigilância Sanitária. (1999). Resolução $\mathrm{n}^{\circ}$ 18, de 30 de Abril de 1999. Regulamento técnico que estabelece as diretrizes básicas para análise e comprovação de propriedades funcionais e ou de saúde alegadas em rotulagem de alimentos. Diário Oficial [da] República Federativa do Brasil.

Brasil. Agência Nacional de Vigilância Sanitária. (2003). Resolução RDC n 359, de 23 de dezembro de 2003. Regulamento Técnico de Porções de Alimentos Embalados para Fins de Rotulagem Nutricional. Diário Oficial [da] República Federativa do Brasil.
Brasil. Ministério da Agricultura, Pecuária e Abastecimento. (2007). Instrução Normativa no 46 de 23 de outubro de 2007. Regulamento Técnico de Identidade e Qualidade de Leites Fermentados. Diário Oficial [da] República Federativa do Brasil.

Carr, J. P., \& Ibrahim, S. A. (2006). Viability of bifidobacteria in commercial yogurt products in North Carolina during refrigerated storage. International Journal of Dairy Technology, 59(4), 272-277. http://dx.doi.org/10.1111/j.1471-0307.2006.00282.x.

Charalampopoulos, D., \& Rastall, R. A. (2012). Prebiotics in foods. Current Opinion in Biotechnology, 23(2), 187-191. PMid:22244693. http://dx.doi.org/10.1016/j.copbio.2011.12.028.

Cochran, W. G., \& Cox, G. M. (1992). Experimenta designs (2. ed.). New York: John Willey \& Sons.

Corrêa, S. B. M., Castro, I. A., \& Saad, S. M. I. (2008). Probiotic potential and sensory properties of coconut flan supplemented with Lactobacillus paracasei and Bifidobacterium lactis. International Journal of Food Science \& Technology, 43(9), 1560-1568. http:// dx.doi.org/10.1111/j.1365-2621.2007.01585.x.

Coussement, P. A. A. (1999). Inulin and oligofructose: safe intakes and legal status. The Journal of Nutrition, 129(7, Suppl), 1412-1417. PMid:10395609.

Cruz, A. G., Cadena, R. S., Walter, E. H. M., Mortazavian, A. M., Granato, D., Faria, J. A. F., \& Bolini, H. M. A. (2010). Sensory analysis: relevance for prebiotic, probiotic and synbiotic product development. Comprehensive Reviews in Food Science and Food Safety, 9(4), 358-373. http://dx.doi.org/10.1111/j.1541-4337.2010.00115.x.

Cruz, A. G., Castro, W. F., Faria, J. A. F., Bolini, H. M. A., Celeghini, R. M. S., Raices, R. S. L., Oliveira, C. A. F., Freitas, M. Q., Conte Júnior, C. A., \& Mársico, E. T. (2013a). Stability of probiotic yogurt added with glucose oxidase in plastic materials with different permeability oxygen rates during the refrigerated storage. Food Research International, 51(2), 723-728. http://dx.doi.org/10.1016/j. foodres.2013.01.028.

Cruz, A. G., Cavalcanti, R. N., Guerreiro, L. M. R., Sant'Ana, A. S., Nogueira, L. C., Oliveira, C. A. F., Deliza, R., Cunha, R. L., Faria, J. A. F., \& Bolini, H. M. A. (2013b). Developing a prebiotic yogurt: rheological, physico-chemical and microbiological aspects and adequacy of survival analysis methodology. Journal of Food Engineering, 114(3), 323-330. http://dx.doi.org/10.1016/j.jfoodeng.2012.08.018.

Dave, R. I., \& Shah, N. P. (1997). Viability of yoghurt and probiotic bacteria in yoghurts made from commercial starters cultures. International Dairy Journal, 7(1), 31-41. http://dx.doi.org/10.1016/ S0958-6946(96)00046-5.

Delgado, G. T. C., Tamashiro, W. M. S. C., Maróstica, M. R. M. Jr., \& Pastore, G. M. (2013). Yacon (Smallanthus sonchifolius): a functional food. Plant Foods for Human Nutrition (Dordrecht, Netherlands), 68(3), 222-228. PMid:23709016. http://dx.doi.org/10.1007/s11130013-0362-0.

Drake, M. A., Miracle, R. E., \& McMahon, D. J. (2010). Impact of fat reduction on flavour and flavour chemistry of cheddar cheeses. Journal of Dairy Science, 93(11), 5069-5081. PMid:20965321. http:// dx.doi.org/10.3168/jds.2010-3346.

Drewnowski, A., \& Darmon, N. (2005). The economics of obesity: dietary energy density and energy cost. The American Journal of Clinical Nutrition, 82(1, Suppl), 265-273. PMid:16002835.

Food and Agriculture Organization of the United Nations. (2003). Codex standard for fermented milks 243. Rome: FAO.

Franck, A. (2006). Inulin. In A. Stephen, Food polysaccharides and their applications (2nd ed.). New York: Ed. Marcel Dekker. 
Ghasemlou, M., Gharibzahedi, S. M. T., \& Emam-Djomeh, Z. (2013). Relating consumer preferences to textural attributes of cooked beans: Development of an industrial protocol and microstructural observations. LWT - Food Science and Technology (Campinas.), 50(1), 88-98.

Glanz, K., Basil, M., Maibach, E., Goldberg, J., \& Snyder, D. A. N. (1998). Why Americans eat what they do: Taste, nutrition, cost, convenience, and weight control concerns as influences on food consumption. Journal of the American Dietetic Association, 98(10), 1118-1126. PMid:9787717. http://dx.doi.org/10.1016/S0002-8223(98)00260-0.

Granato, D., Pekarski, F. V. B. W., Benincá, C., \& Masson, M. L. (2009). Doce dietético misto de yacon e maracujá: Avaliação da aceitabilidade e da estabilidade físico-química sob refrigeração. Brazilian Journal of Food Technology, 12(3), 200-204. http://dx.doi.org/10.4260/ BJFT2009800900013.

Hinkelmann, K., \& Kempthorne, O. (1994). Design and analysis of experiments (Vol. 1). New York: John Wiley \& Sons.

International Dairy Federation. (1988). Fermented milks: science and technology (IDF Bulletin, 227). Brussels: IDF.

International Organization for Standardization. (2007). ISO 8589: sensory analysis: general guidance for the design of test rooms. Genéve: ISO.

Karimi, R., Azizi, M. H., Ghasemlou, M., \& Vaziri, M. (2015). Application of inulin in cheese as prebiotic, fat replacer and texturizer: a review. Carbohydrate Polymers, 119, 85-100. PMid:25563948. http://dx.doi. org/10.1016/j.carbpol.2014.11.029.

Komatsu, T. R., Buriti, F. C. A., \& Saad, S. M. I. (2008). Inovação, persistência e criatividade superando barreiras no desenvolvimento de alimentos probióticos. Brazilian Journal of Pharmaceutical Sciences, 44(3), 329-347.

Kristo, E., Biliaderis, C. G., \& Tzanetakis, N. (2003). Modelling of rheological, microbiological and acidification properties of a fermented milk product containing a probiotic strain of Lactobacillus paracasei. International Dairy Journal, 13(7), 517-528. http://dx.doi. org/10.1016/S0958-6946(03)00074-8.

Kumar, H., Salminen, S., Verhagen, H., Rowland, I., Heimbach, J., Bañares, S., Young, T., Nomoto, K., \& Lalonde, M. (2015). Novel probiotics and prebiotics: road to the market. Current Opinion in Biotechnology, 32, 99-103. PMid:25499742. http://dx.doi.org/10.1016/j. copbio.2014.11.021.

Lollo, P. C. B., Morato, P. N., Moura, C. S., Oliveira, M. M., Cruz, A. G., Faria, J. A. F., Amaya-Farfan, J., \& Cristianini, M. (2015). Ultra-high temperature plus dynamic high pressure processing: an effective combination for potential probiotic fermented milk processing which attenuate exercise-induced immune suppression in Wistar rats. Journal of Functional Foods, 14, 541-548. http://dx.doi. org/10.1016/j.jff.2015.01.009.

Lollo, P. C. B., Moura, C. S., Morato, P. N., Cruz, A. G., Castro, W. F., Betim, C. B., Nisishima, L., Faria, J. A. F., Maróstica, M., Fernandes, C. O., \& Amaya-Farfan, J. (2013). Probiotic yogurt offers higher immuneprotection than probiotic whey beverage. Food Research International, 54(1), 118-124. http://dx.doi.org/10.1016/j.foodres.2013.06.003.

Maganha, L. C., Rosim, R. E., Corassin, C. H., Cruz, A. G., Faria, J. A. F., \& Oliveira, C. A. F. (2014). Viability of probiotic bacteria in fermented skim milk produced with different levels of milk powder and sugar. International Journal of Dairy Technology, 67(1), 89-94. http://dx.doi.org/10.1111/1471-0307.12087.

Meilgaard, M., Civille, G. V., \& Carr, B. T. (2007). Sensory evaluation techniques (4th ed.). Boca Raton: CRC Press.

Minim, V. P. R. (2013). Análise sensorial: estudos com consumidores (3. ed.). Viçosa: UFV.
Morais, E. C., Morais, A. R., Cruz, A. G., \& Bolini, H. M. A. (2014). Development of chocolate dairy dessert with addition of prebiotics and replacement of sucrose with different high-intensity sweeteners. Journal of Dairy Science, 97(5), 2600-2609. PMid:24612793. http:// dx.doi.org/10.3168/jds.2013-7603.

Moreno, Y., Collado, M. C., Ferrús, M. A., Cobo, J. M., Hernández, E., \& Hernández, M. (2006). Viability assessment of lactic acid bacteria in commercial dairy products stored at $4^{\circ} \mathrm{C}$ using LIVE/ DEAD BacLightTM staining and conventional plate counts. International Journal of Food Science \& Technology, 41(3), 275-280. http://dx.doi. org/10.1111/j.1365-2621.2005.01060.x.

Moscatto, J. A., Borsato, D., Bona, E., Oliveira, A. S., \& Oliveira, M. C. H. (2006). The optimization of the formulation for a chocolate cake containing inulin and yacon meal. International Journal of Food Science \& Technology, 41(2), 181-188. http://dx.doi.org/10.1111/j.13652621.2005.01047.x.

Myers, R. H., \& Montgomery, D. C. (2002). Response surface methodology (2nd ed.). New York: John Wiley and Sans.

Niness, K. R. (1999). Inulin and oligofructose: what are they? The Journal of Nutrition, 129(7, Suppl), 1402-1406. PMid:10395607.

Nogueira, M. O. (2009). Tecnologia de produtos lácteos funcionais. São Paulo: Atheneu.

Ojansivu, I., Ferreira, C. L., \& Salminen, S. (2011). Yacon, a new source of prebiotic oligosaccharides with a histoty of safe use. Trends in Food Science \& Technology, 22(1), 40-46. http://dx.doi.org/10.1016/j. tifs.2010.11.005.

Oliveira, L. F., Correa, J. F. G., Pereira, M. C. a., Ramos, A. L. S., \& Vilela, M. B. (2016). Osmotic dehydration of yacon (Smallanthus sonchifolius): optimization for fructan retention. LWT - Food Science and Technology (Campinas.), 71, 77-87.

Oliveira, M. N., Sodini, I., Remeuf, F., Tissier, J. P., \& Corrieu, G. (2002). Manufacture of fermented lactic beverages containing probiotic cultures. Journal of Food Science, 67(6), 2336-2341. http://dx.doi. org/10.1111/j.1365-2621.2002.tb09550.x.

Pandey, S. M., \& Mishra, H. N. (2015). Optimization of the prebiotic \& probiotic concentration and incubation temperature for the preparation of synbiotic soy yoghurt using response surface methodology. LWT - Food Science and Technology (Campinas.), 62, 458-467.

Pimentel, T. C., Cruz, A. G., \& Prudencio, S. H. (2013). Short communication: Influence of long-chain inulin and Lactobacillus paracasei subspecies paracasei on the sensory profile and acceptance of a traditional yogurt. Journal of Dairy Science, 96(10), 6233-6241. PMid:23932139. http://dx.doi.org/10.3168/jds.2013-6695.

Roberfroid, M. (2007). Prebiotics: the concept revisited. The Journal of Nutrition, 137(3, Suppl 2), 830-837. PMid:17311983.

Rodrigues, M. I., \& Iemma, A. F. (2009). Planejamento de experimentos e otimização de processos: uma estratégia seqüencial de planejamentos (2. ed.). São Paulo: Casa do Pão.

Saad, N., Delattre, C., Urdaci, M., Schmitter, J. M., \& Bressollier, P. (2013). An overview of the last advances in probiotic and prebiotic field. LWT - Food Science and Technology (Campinas.), 50(1), 1-16. http://dx.doi.org/10.1016/j.lwt.2012.05.014.

Saarela, M., Mogensen, G., Fonden, R., Matto, J., \& Mattila-Sandholm, T. (2000). Probiotic bacteria: safety, functional and technological properties. Journal of Biotechnology, 84(3), 197-215. PMid:11164262. http://dx.doi.org/10.1016/S0168-1656(00)00375-8.

Saccaro, D. M., Tamime, A. Y., Pilleggi, A. L. O. P. S., \& Oliveira, M. N. (2009). The viability of three probiotic organisms grown with yoghurt starter cultures during storage for 21 days at $4^{\circ} \mathrm{C}$. 
International Journal of Dairy Technology, 62(3), 397-404. http:// dx.doi.org/10.1111/j.1471-0307.2009.00497.x.

Sanchez, B., Reyes-Gavilán, C. G. L., Margolles, A., \& Gueimonde, M. (2009). Probiotic fermented milks: present and future. International Journal of Dairy Technology, 62(4), 1-10. http://dx.doi.org/10.1111/ j.1471-0307.2009.00528.x.

Santos, R. B., Barbosa, L. P. J. L., \& Barbosa, F. H. F. (2011). Probióticos: microrganismos funcionais. Ciência Equatorial, 1(2), 26-38.

Saxelin, M., Grenov, B., Svensson, U., Fonden, R., Reniero, R., \& MattilaSandholm, T. (1999). The technology of probiotics. Trends in Food Science \& Technology, 10(12), 387-392. http://dx.doi.org/10.1016/ S0924-2244(00)00027-3.

Shah, N. P., \& Ravela, R. R. (2000). Influence of water activity on fermentation, organic acids production and viability os yoghurt and probiotic bacteria. Australian Journal of Dairy Technology, 55(3), 127-131.

Shen, R., Luo, S., \& Dong, J. (2011). Application of oat dextrine for fat substitute in mayonnaise. Food Chemistry, 126(1), 65-71. http:// dx.doi.org/10.1016/j.foodchem.2010.10.072.

Shi, Q., Zheng, Y., \& Zhao, Y. (2015). Thermal transition and state diagram of yacon dried by combined heat pump and microwave method. Journal of Thermal Analysis and Calorimetry, 119(1), 727735. http://dx.doi.org/10.1007/s10973-014-4198-0.

Sousa, S., Pinto, J., Pereira, C., Malcata, F. X., Pacheco, M. T. B., Gomes, A. M., \& Pintado, M (2015). In vitro evaluation of yacon (Smallanthus sonchifolius) tuber flour prebiotic potential. Food and Bioproducts Processing, 95, 96-105. http://dx.doi.org/10.1016/j.fbp.2015.04.003.

Srisuvor, N., Chinprahast, N., Prakitchaiwattana, C., \& Subhimaros, S. (2013). Effects of inulin and polydextrose on physicochemical and sensory properties of low-fat set yoghurt with probiotic-cultured banana purée. LWT - Food Science and Technology (Campinas.), 51(1), 30-36.

Thamer, K. G., \& Penna, A. L. B. (2005). Efeito do teor de soro, açúcar e de frutooligossacarídeos sobre a população de bactérias lácticas probióticas em bebidas fermentadas. Revista Brasileira de Ciências
Farmacêuticas, 41(3), 393-400. http://dx.doi.org/10.1590/S151693322005000300013.

Tharmaraj, N., \& Shah, N. P. (2003). Selective enumeration of Lactobacillus delbrueckii ssp. bulgaricus, Streptococcus thermophilus, Lactobacillus acidophilus, Bifidobacteria, Lactobacillus casei, Lactobacillus rhamnosus, and Propionibacteria. Journal of Dairy Science, 86(7), 2288-2296. PMid:12906045. http://dx.doi.org/10.3168/jds.S00220302(03)73821-1.

Velez, E., Castillo, N., Mesón, O., Grau, A., Bonet, M. E. B., \& Perdigón, G. (2013). Study of the effect exerted by fructo-oligosaccharides from yacon (Smallanthus sonchifolius) root flour in an intestinal infection model with Salmonella Typhimurium. British Journal of Nutrition, 109(11), 1971-1979. PMid:23137694. http://dx.doi. org/10.1017/S0007114512004230.

Villegas, B., Tárrega, A., Carbonell, I., \& Costell, E. (2010). Optimising acceptability of new prebiotic low-fat milk beverages. Food Quality and Preference, 21(2), 234-242. http://dx.doi.org/10.1016/j. foodqual.2009.03.001.

Vinderola, C. G., Bailo, N., \& Reinheimer, A. J. (2000). Survival of probiotic microflora in argentinian yoghurts during refrigerated storage. Food Research International, 33(2), 97-102. http://dx.doi. org/10.1016/S0963-9969(00)00011-9.

Vitali, B., Ndagijimana, M., Maccaferri, S., Biagi, E., Guerzoni, M. E., \& Brigidi, P. (2012). An in vitro evaluation of the effect of probiotics and prebiotics on the metabolic profile of human microbiota. Anaerobe, 18(4), 386-391. PMid:22579985. http://dx.doi.org/10.1016/j. anaerobe.2012.04.014.

Wang, S., Zhu, H., Lu, C., Kang, Z., Luo, Y., Feng, L., \& Lu, X. (2012). Fermented milk supplemented with probiotics and prebiotics can effectively alter the intestinal microbiota and immunity of host animals. Journal of Dairy Science, 95(9), 4813-4822. PMid:22916885. http://dx.doi.org/10.3168/jds.2012-5426.

Wendling, L. K., \& Weschenfelder, S. (2013). Probiotics and fermented dairy foods: a review. Revista do Instituto de Laticínios Cândido Tostes, 68(395), 49-57. http://dx.doi.org/10.5935/2238-6416.20130048. 